\title{
ZONA DE CISALHAMENTO DO NÚCLEO DO ANTICLINÓRIO DE GOUVEIA, CORDILHEIRA DO ESPINHAÇO, MG: GEOMETRIA, CINEMÁTICA E PROCESSOS DEFORMACIONAIS
}

\author{
SIMONE CERQUEIRA PEREIRA CRUZ ${ }^{1}$, FERNANDO FLECHAALKMIM ${ }^{1} \&$ \\ LEONARDO EVANGELISTA LAGOEIRO ${ }^{1}$
}

\begin{abstract}
Resumo O Anticlinório de Gouveia, uma culminação antiformal de idade neoproterozóica nucleada pelo embasamento no Cinturão de Dobramentos e Cavalgamentos do Espinhaço Meridional (MG), está estruturado por uma série de falhamentos ancorados no embasamento e por dobramentos em pequena escala, ambos vergentes para oeste. Uma análise detalhada em diversas escalas de observação foi realizada ao longo de um segmento de duas dessas falhas que foram nucleadas no complexo arqueano denominado granito de Gouveia, aqui denominado de granitóide de Gouveia. Esse estudo revelou que a deformação da cobertura foi acomodada no embasamento do núcleo do Anticlinório de Gouveia por meio da nucleação de zonas de cisalhamento dúctil-rúpteis. Tais zonas são constituídas por uma associação de rochas miloníticas e filoníticas e alcançam mergulhos de até $60^{\circ}$, diferentemente da sua continuação na cobertura. Esse mergulho anômalo reflete o controle estrutural exercido pela foliação primária do granitóide de Gouveia sobre a geometria das zonas de cisalhamento estudadas. Indicadores cinemáticos de vários tipos revelam duas fases principais de deformação. A primeira, com cinemática reversa sinistral, possui vergência para oeste e foi responsável pela nucleação das zonas de cisalhamento. A segunda, com movimentação normal destral, desenvolve-se por meio da reativação de porções das zonas anteriormente nucleadas. Os principais processos observados na escala de grão nas zonas de cisalhamento estudadas foram o microfraturamento e deslizamento friccional em grãos de feldspato e biotita, deformação cristalplástica em quartzo e processos envolvendo transferência de soluções. A circulação de fluidos foi um processo ativo em ambas as fases de deformação levando à instalação de reações de hidratação e substituição do K-feldspato pelo plagioclásio, dissolução/precipitação de quartzo e crescimento de turmalina e barita. Como resultado disso, as zonas estudadas são dominadas por rochas protomiloníticas e filoníticas. As condições de temperatura estimadas para a deformação varia entre 300 e $400^{\circ} \mathrm{C}$ e o metamorfismo alcança temperatura de $500^{\circ} \mathrm{C}$.
\end{abstract}

Palavras-chave: protomilonitos, milonitos, filonitos, transferência de solução, zona de cisalhamento.

Abstract The Gouveia Anticlinorium, a basement-cored antiformal culmination of the Neoproterozoic Araçuaí fold-thrust belt in eastern Brazil, is made up by a series of west-verging basement-involved thrusts in association with smaller scale folds. A detailed macro-to-microstructural analysis was carried out along the segments of two of these thrusts, where they affect the Gouveia granite in the Archean basement complex. This study revealed that the deformation of the cover was accommodated in the basement core of the anticlinorium by discrete ductile-brittle shear zones, marked by up to $700 \mathrm{~m}$ thick bands of mylonitic and plyllonitic rocks. In comparison with their continuation in the cover, the basement shear zones are significantly steeper, showing dips in the order of $60^{\circ}$. These anomalous dips reflect a magmatic foliation displayed by the Gouveia Granite, which exerted a major control on the geometry of the shear zones. Kinematic indicators of various categories record two phases of motion. A first west-verging reverse-sinistral motion was coupled with the nucleation of the shear zones. A normal-dextral reactivation took place during a subsequent phase of extensional tectonism. The main processes involved in the development and evolution of these structures were fracturing and friccional grain boundary sliding of feldspars, plastic deformation of quartz and biotite, and solution transfer. Fluids circulation was very active during both phases of deformation, causing hydratation of the feldspars, quartz dissolution and re-precipitation and tourmaline and barite growth. As a consequence, the studied shear zones are dominated by protomylonites and phyllonites. Estimated temperature conditions for the deformation processes fall in the range of 300 and $400^{\circ} \mathrm{C}$.

Keywords: protomylonites, mylonites, phyllonites, solution transfer, shear zone.

\author{
INTRODUÇÃO O substrato dos cinturões orogenéticos \\ consiste, em geral, de um complexo de rochas cristalinas que no \\ curso dos processos tectônicos comporta-se de forma bastante \\ distinta da cobertura sedimentar. Apesar da enorme quantidade \\ de estudos existentes acerca dos cinturões de dobramentos e \\ cavalgamentos, muitas questões sobre esse sistema tectônico \\ ainda permanecem sem resposta definitiva, tais como: \\ - Como interagem embasamento e cobertura no curso da \\ deformação? \\ - Como é absorvida a deformação pelas rochas do \\ embasamento? \\ - Qual o papel dos fluidos durante a deformação das rochas
}

cristalinas do embasamento?

Nos arredores da cidade de Gouveia, Minas Gerais, está exposta a zona periclinal de uma das estruturas mais proeminentes da cordilheira do Espinhaço Meridional (Figs. 1 e 2). Trata-se do Anticlinal ou Anticlinório de Gouveia (Pflug 1965), que é nucleado pelo embasamento arqueano e rochas alcalinas neoproterozóicas (Dussin et al. 1992, 1996; Dussin 1994) e moldado nos metassedimentos paleo-mesoproterozóicos do Supergrupo Espinhaço (Almeida Abreu et al. 1992, Dussin, I. A. 1994, Fogaça et al. 1984, Uhlein et al. 1986, Uhlein 1991, Alkmim 1995).

No núcleo do Anticlinório de Gouveia uma série de falhas de empurrão cartografadas na cobertura (Almeida Abreu 1985, Uhlein 
1991, Fogaça 1996, Knauer \& Fogaça 1996) adentram pelo embasamento e se transformam em largas zonas de cisalhamento dúctil-rúpteis, marcadas por rochas da série milonítica e por filonitos geradas no curso do Evento Brasiliano (Alkmim 1995, Dussin I.A et al. 1992, 1995).

No presente trabalho, descrevem-se a geometria, a evolução cinemática e os processos deformacionais observados em duas das várias zonas de cisalhamento que cortam o embasamento arqueano e a cobertura proterozóica na porção norte do Anticlinório de Gouveia. Demonstra-se que, neste caso, falhas de empurrão e dobras da cobertura são representadas, no embasamento, por espessas zonas de cisalhamento dúctil-rúpteis reversas, que separam domínios totalmente isentos de estruturas deformacionais. Marcadas por rochas da série milonítica e, especialmente, por filonitos, essas zonas de cisalhamento registraram toda a história cinemática da região.

\section{A ZONA PERICLINAL DOANTICLINÓRIO DE GOUVEIA}

Estratigrafia OAnticlinório de Gouveia, no seu domínio periclinal norte, exposto nas proximidades da cidade homônima, envolve um embasamento de granitóides arqueanos e os metassedimentos dos supergrupos Rio Paraúna e Espinhaço de idades arqueana e paleo/mesoproterozóica, respectivamente (Fig. 2).

No embasamento distinguem-se migmatitos, gnaisses e granitóides. Na área objeto do presente estudo (Fig. 3), o complexo do embasamento é representado pelo granito de Gouveia, aqui denominado de granitóide de Gouveia, já que na realidade consiste de uma assembléia de rochas calcioalcalinas, com composição variando entre granitos, monzogranitos e sienitos, e alcalinas, de composição variando predominantemente sienítica. Nos termos porfiríticos das unidades calcioalcalinas a foliação é primária marcada pela orientação preferencial de cristais de K-feldspato, com atitude modal em 084/76. Datações utilizando o sistema U/Pb em zircões extraídos do granitóide de Gouveia forneceram idades

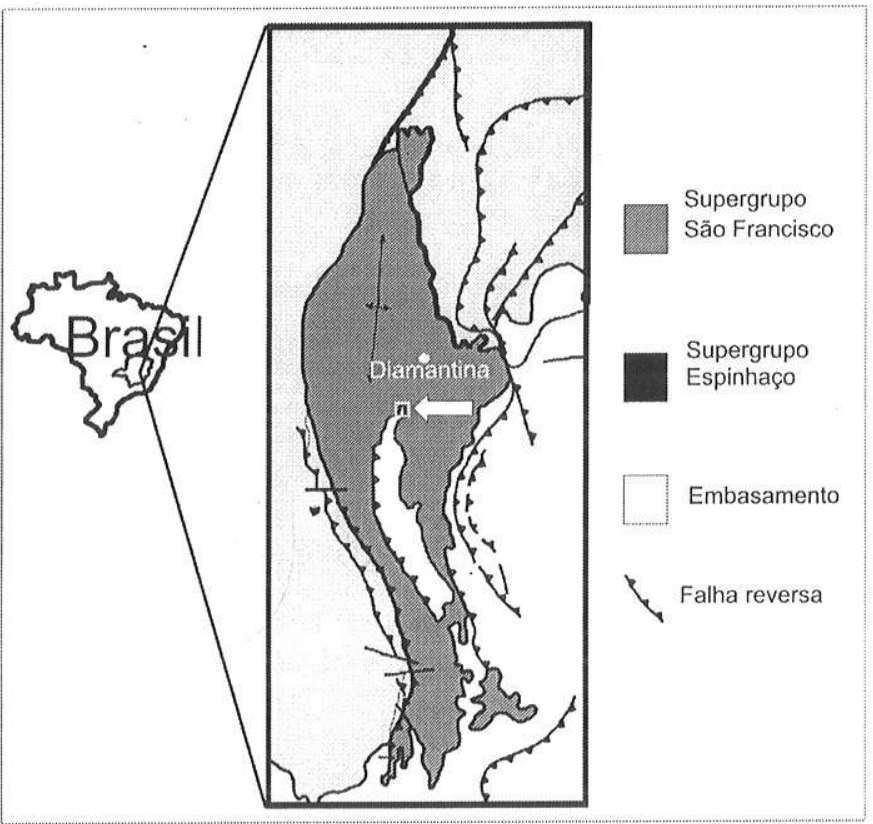

Figura 1 - Localização do Anticlinório de Gouveia na serra do Espinhaço Meridional (Modificado de Schobbenhaus 1981). A seta branca indica a área apresentada na figura 2. de 2,84 Ga para a sua cristalização (irachado et al.1989). A associação alcalina engloba rochas que foram classificadas como laprófiros por Dussin I. A et al. (1992, 1996) e Dussin, T. M. (1994).

O Supergrupo Rio Paraúna aflora na porção nordeste da área estudada (Fig. 3) e engloba rochas predominantemente epiclásticas, com contribuições subordinadas máficas e félsicas do Grupo Costa Sena (Fogaça et. al. 1984).

O Supergrupo Espinhaço está representado pelas formações Bandeirinha, São João da Chapada, Sopa Brumadinho e Galho do Miguel (Almeida Abreu 1985, Uhlein 1991, Fogaça 1996, Knauer \& Fogaça 1996). Dominadas por quartzitos, estas unidades contêm, localmente, intercalações de pelitos e conglomerados.

Rochas básicas em diques e sills cortam todas as unidades previamente mencionadas. São diabásios e gabros (Silva 1995) que, dependendo das dimensões, forma e orientação espacial dos seus corpos, mostram variados graus de deformação e xistificação.

O metamorfismo que afeta as unidades do Anticlinório de Gouveia é de fácies xisto verde, com associação mineralógica representada por quartzo, cianita, clorita, biotita verde, epidoto e mica branca (Schöll \& Fogaça 1979, Hoffmann \& Hoppe 1981,

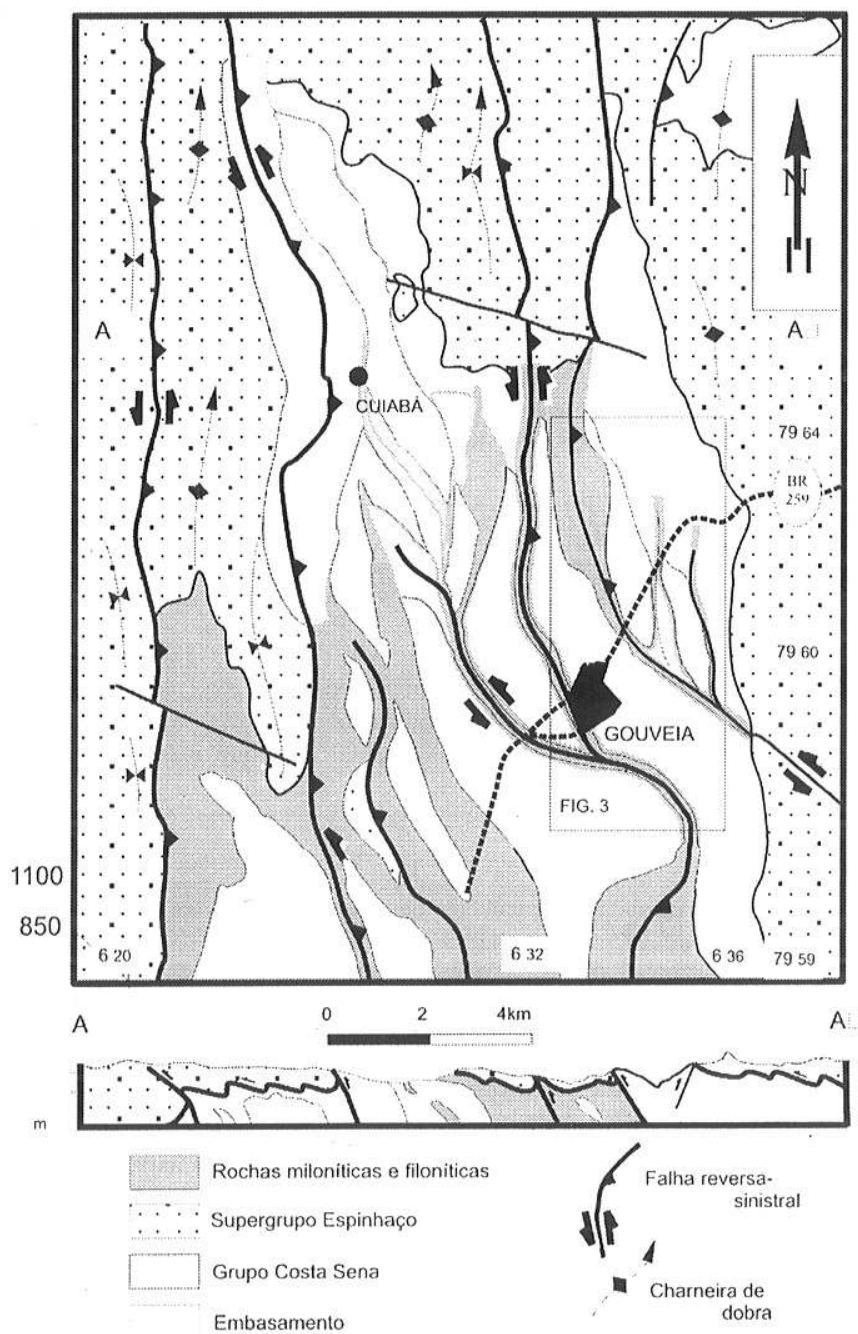

Figura 2 - Zona Periclinal do Anticlinal de Gouveia (MG), modificado de Alkmim (1995). O retângulo indica a área a ser detalhada na figura 3. 
Hoffmann 1983, Dossin e: al 1984, Fogaça \& Schöll 1984, Almeida Abreu 1989, Rosière et al. 1994, Dussin et al. 1992, 1995, Cruz 2000).

Arcabouço estrutural O Anticlinório de Gouveia, com um comprimento de onda de cerca de $28 \mathrm{~km}$, é balizado a oeste pelo Sinclinório de Conselheiro Mata e a leste por um arco sinformal curto, sucedido por um grande leque de falhas de empurrão vergentes para oeste em associação com uma grande estrutura antiformal. A orientação da sua charneira na porção setentrional é NS, com caimento médio de $15^{\circ}$ para norte (Almeida Abreu 1985, Schöll \& Fogaça 1981, Alkmim 1995, Dussin et al. 1992, 1995). A sua porção meridional inflete progressivamente para SE e, no mesmo sentido, passa a cair a sua charneira.

Na zona periclinal do Anticlinório de Gouveia distinguem-se grandes zonas de falha de empurrão (Almeida Abreu 1985, Schöll \& Fogaça 1981, Alkmim 1995, Fogaça 1996, Knauer \& Fogaça 1996) (Fig. 3) que, ancoradas no embasamento, avançam pela cobertura, a norte, perdendo progressivamente o seu rejeito.

No domínio do embasamento, as zonas de falha apresentamse como zonas de cisalhamento dúctil-rúpteis (Dussin et al. 1992, 1995) com espessuras variáveis entre uma dezena a várias centenas de metros. Orientam-se, preferencialmente, segundo 090/60 e exibem, internamente, uma trama anastomótica, na qual as inúmeras interconexões delimitam núcleos sigmoidais menos deformados. Possuem rico acervo de indicadores cinemáticos que atestam movimentação geral reversa sinistral, localmente revertida para normal a normal destral (Fig. 4). São marcadas no campo pela presença de rochas da série milonítica e de filonitos, além de grande quantidade de veios de quartzo.

\section{ZONA DE CISALHAMENTO DE GOUVEIA}

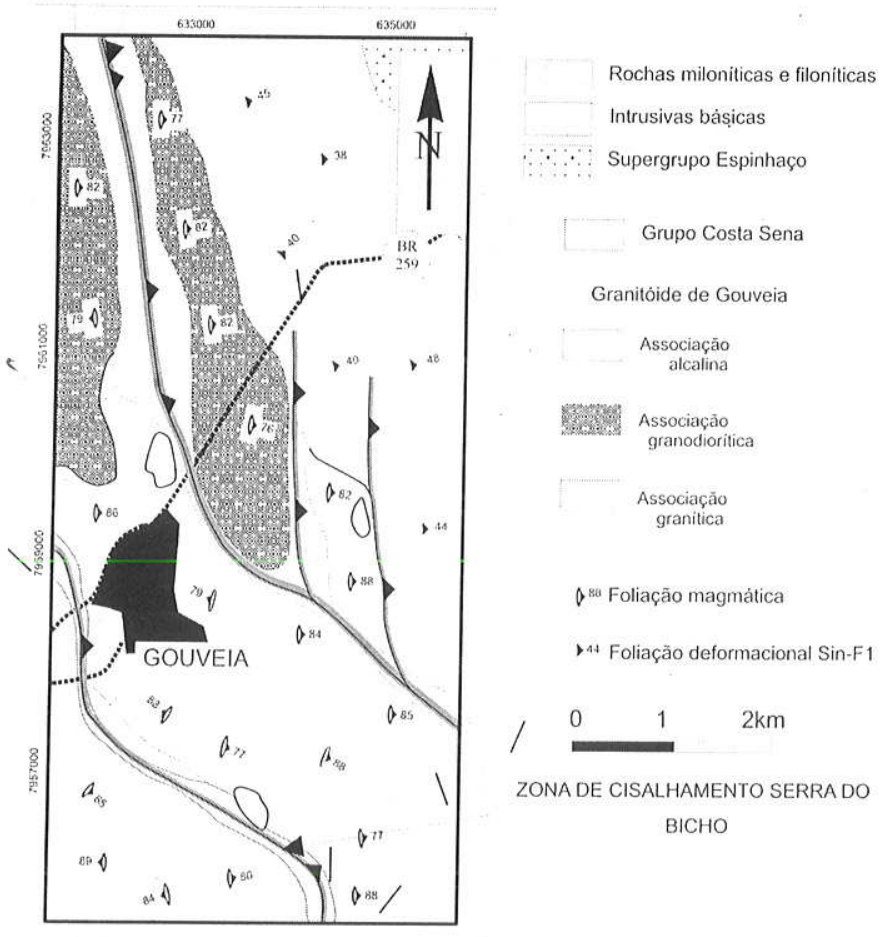

Figura 3 - Mapa Geológico de detalhe da área estudada, com localização indicada na figura 1. Fonte: Cruz (2000).
Na cobertura sedimentar as zonas de falha mostram uma notável redução de sua espessura, que cai para a casa dos decímetros a, no máximo, algumas dezenas de metros. São também acompanhadas de milonitos e grande quantidade de veios de quartzo. Sua atitude oscilam em torno de 090/35. Associam-se a dobras e trens de dobras megascópicas vergentes para oeste, cujas charneiras caem sistematicamente para norte (Fig. 3)

\section{ASZONAS DE CISALHAMENTODEGOUVEIA EDASERRA DO BICHO: GEOMETRIA, CINEMÁTICA E HISTÓRIA} EVOLUTIVA Dentre as cinco zonas de cisalhamento principais da zona periclinal do Anticlinório de Gouveia, duas foram escolhidas para a investigação estrutural de detalhe em seus segmentos alojados no embasamento. Aqui designadas zonas de cisalhamento de Gouveia e da Serra Bicho (Fig. 3), estão localizadas na porção leste da zona periclinal, nas proximidades da cidade de Gouveia. Até a vizinhança norte dessa cidade, possuem direção geral NS e um mergulho médio de cerca de $60^{\circ}$ para leste. Dali para sul, infletemse progressivamente para SE e tornam-se verticais (Fig. 3). As espessuras de afloramento são extremamente variáveis, entre 125 e $750 \mathrm{~m}$ na zona de Gouveia e entre 60 e $700 \mathrm{~m}$, na zona de

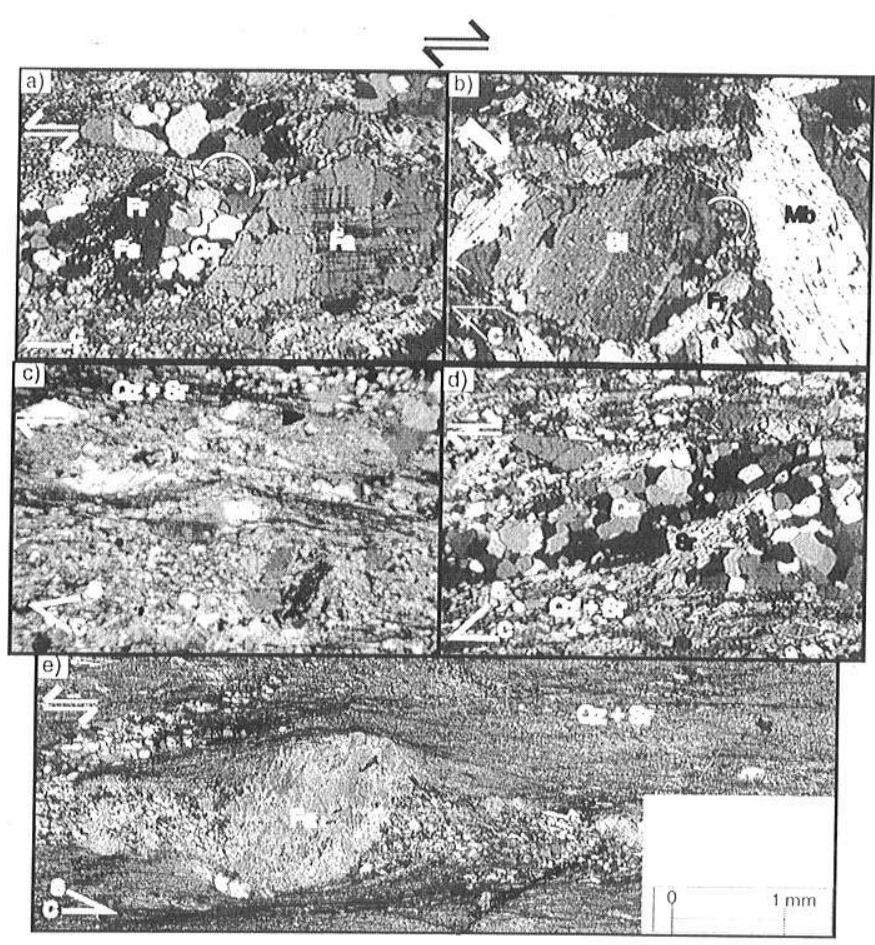

Figura 4 - Indicadores cinemáticos comuns nas zonas de cisalhamento de Gouveia. a e b) Estrutura tipo v-pull apart em feldspato alcalino e biotita, respectivamente. Fr representa o fragmento que possivelmente possui maior velocidade de rotação (segundo Hippertt 1998). c) Estrutura tipo mica-fish em mica branca. d) Foliação S/C em milonitos. e) Sombra de pressão em milonitos. A seta preta refere-se à cinemática da zona de cisalhamento, obtida em amostras de mão através da assimetria da foliação $\mathrm{S} / \mathrm{C}$ e a seta branca refere-se à cinemática indicada pela estrutura em questão. Em cada foto estão indicadas as foliações $S$ elou $C$. Bi=biotita, $M b=$ mica branca, $\mathrm{Sr}=$ mica branca, $F a=K$-feldspato, $Q z=q u a r t z o$. Base da figura $=2 \mathrm{~mm}$. 
cisalhamento da Serra do Bicho.

Um atributo notável destas e de todas as demais zonas de cisalhamento instaladas no embasamento da região é o seu alto mergulho, sempre igual ou superior a $60^{\circ}$. O mergulho esperado para falhamentos de empurrão nucleados em um corpo anisotrópico é de aproximadamente $30^{\circ}$, segundo a teoria de Mohr-Coulomb-

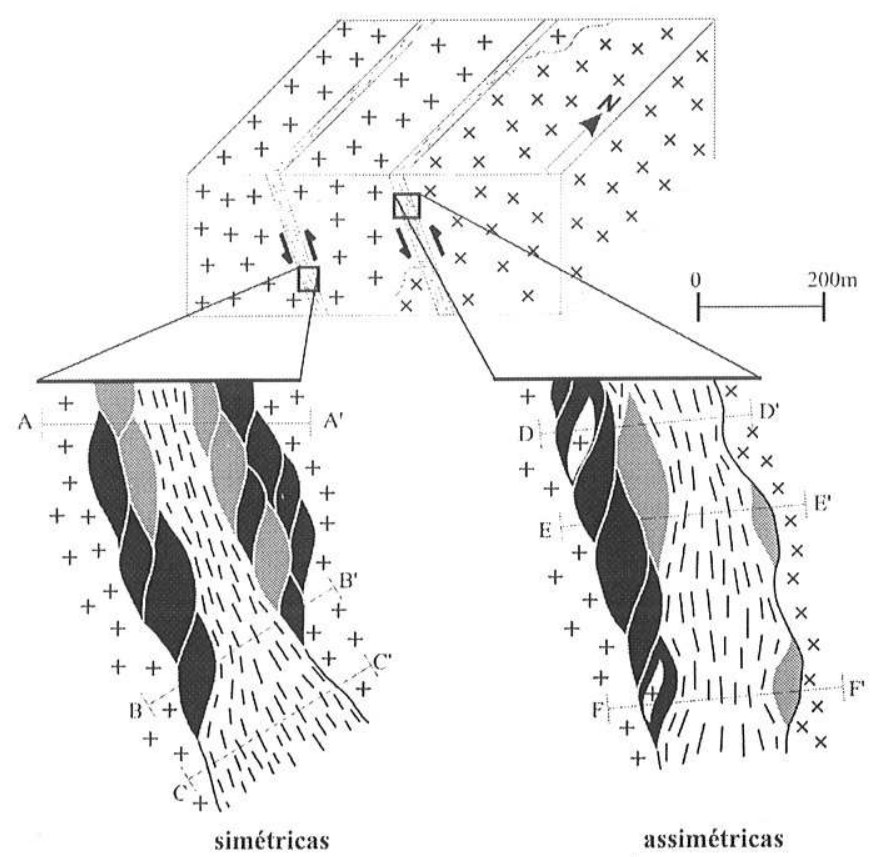

LEGENDA

${ }_{++}^{++}$Associação Granitica

$\times$ Associação quartzo-diorítica a

$\times \times$ granodioritica

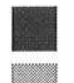

protomilonitos \II filonitos milonitos

Figura 5 - Representação esquemática da geometria interna das zonas de cisalhamento estudadas e da distribuição dos tectonitos no seu interior: $A-A^{\prime}, B-B^{\prime}, C-C^{\prime}, D-D^{\prime}, E-E, F-F^{\prime}$ são variações da simetria interna observadas em afloramentos.
Anderson (Sibson 1990, Ivins et al.1990). Falhamentos com mergulhos superiores ao esperado sugerem controle ou reativação de descontinuidades pré-existentes. Como mencionado anteriormente, o granitóide de Gouveia exibe uma foliação magmática, cuja disposição espacial é muito próxima da atitude das zonas de cisalhamento em questão. Sugere-se, assim, que os mergulhos anormalmente altos tenham sido induzidos pela trama primária.

No interior das zonas de cisalhamento desenvolvidas no embasamento, protomilonitos, milonitos e filonitos (sensu Sibson 1977) se sucedem longitudinal e transversalmente em arranjo lenticular e anastomótico. A distribuição dos diversos tectonitos é, de'maneira geral, simétrica (Fig. 5). Distribuições assimétricas são, todavia, freqüentes.

As foliações nas rochas miloníticas e filoníticas resultam da orientação preferencial curviplanar dos filossilicatos (biotita, clorita e mica branca), dos agregados policristalinos e dos cristais tabulares de quartzo. O seu padrão de distribuição varia entre anastomótico, nos protomilonitos, até contínuo, nos filonitos.

A lineação de estiramento é marcada pela orientação preferencial dos cristais de turmalina, mica branca e biotita, bem como por ribbons policristalinos de quartzo. Na Figura 6 têm-se os diagramas estereográficos da foliação milonítica e da lineação de estiramento. Nela, mostra-se também o diagrama da foliação magmática do granitóide hospedeiro para comparação.

O exame de indicadores cinemáticos associados à foliação e à lineação dos tectonitos revelou a existência de duas etapas principais de deformação.

A nucleação das zonas de cisalhamento deu-se em uma primeira fase de deformação compressional, com tensão principal máxima $\left(s_{1}\right)$ horizontal e orientada segundo ESE-WNW (Cruz 2000). Ao longo dos segmentos de orientação NS e NW-SE das zonas de cisalhamento, estruturas S/C, C', sigmóides de foliação e dobras, indicam uma movimentação geral reversa-sinistral para a primeira fase. Como se pode observar na figura 5, a lineação de estiramento é de alta obliqüidade e preferencialmente orientada em 095/71. Nos segmentos de orientação NW-SE, os mesmos indicadores cinemáticos atestam movimentos sinistrais a reversos sinistrais. Nestes, a lineação de estiramento mostra obliqüidades variáveis entre $0^{\circ}-30^{\circ}$. Associados a essa fase, foram nucleados veios de quartzo com atitude modal 095/10. a)

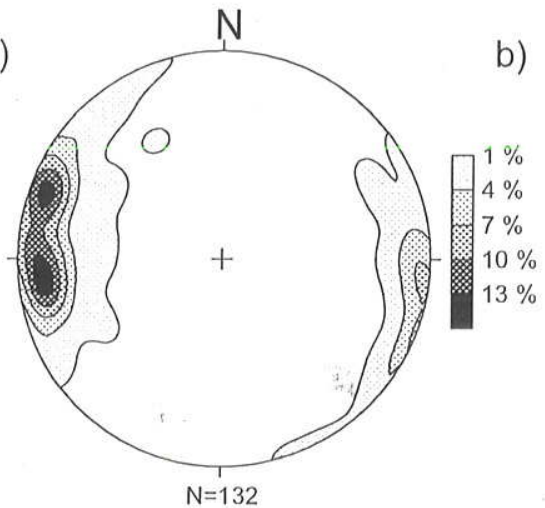

Max: 084/76

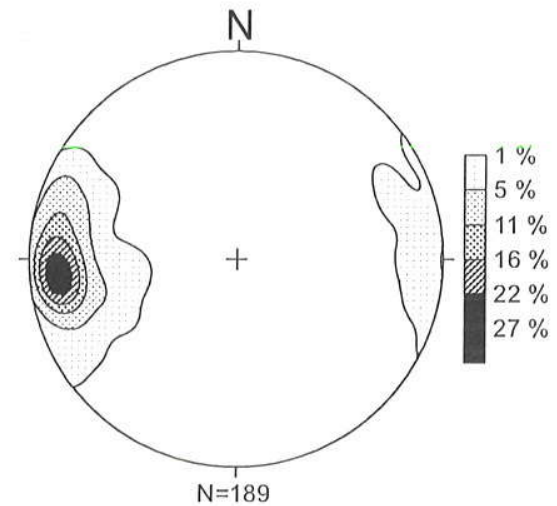

Max:085/75

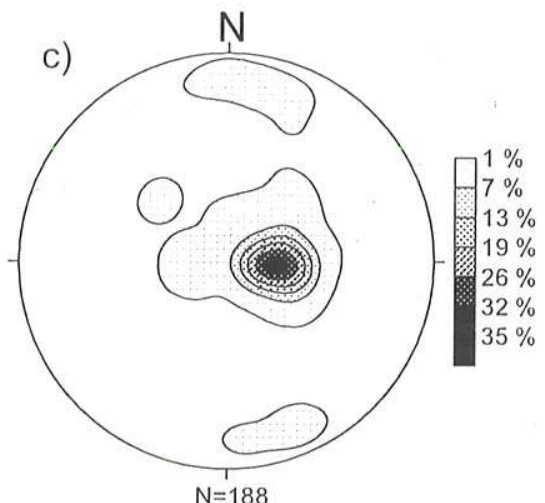

Max: 095/71

Figura 6 - Diagramas estereográficos dos pólos da foliação magmática do granitóide de Gouveia (a), da foliação deformacional e da lineação de estiramento nas zonas de cisalhamento de Gouveia e da Serra do Bicho (b e c, respectivamente). 
Durante a segunda fase de deformação, as zonas previamente nucleadas foram reativadas em regime distensional. Indicadores cinemáticos de várias categorias atestam movimentos normais a normais-destrais. Nesta fase houve o desenvolvimento de uma segunda geração de veios de quartzo, cuja atitude modal é 090/80.

Embora os indicadores de movimentação reversa-sinistral sejam dominantes regionalmente, indicadores superimpostos de movimentação normal podem ser observados em quase todos os locais, inclusive nas porções das zonas de cisalhamento orientadas segundo NS, chegando mesmo a serem os únicos observáveis nos domínios de intensa filonitização. Porém, nas zonas estudadas, é comum o caso em que, em um mesmo afloramento ou amostra de mão, indicadores de natureza e escalas distintas atestem movimentos de sentidos opostos. Também é frequiente a alternância entre setores com indicadores reversos e setores com indicadores normais, ao longo de uma mesma zona. Em todos os setores onde predominam indicadores de movimento normal tem-se intensa fillonitização. A recíproca não é, porém, verdadeira. Por outro lado, domínios em que houve intenso aporte de quartzo em forma de veios, os indicadores presentes atestam, invariavelmente, movimento reverso. Isto sugere os veios tenham agido como cicatrizantes, impedindo a reativação destes setores.

A associação mineralógica sintectônica às duas fases de deformação é representada pela mica branca, quartzo, clorita, biotita verde, pirita, epidoto sensu strictu, clinozoizita/zoizita, turmalina, albita, rutilo, titanita, barita, ilmenita e calcita. Como associação pós-tectônica, foram identificados çianita, moscovita, turmalina, pirita e cloritóide.

\section{PROCESSOS DEFORMACIONAIS E REAÇÕES METASSOMÁTICAS NO GRANITÓIDE DE GOUVEIA Microfraturamento e deslizamento friccional (frictional grain boundary sliding) Esses processos levaram à diminuição do tamanho dos feldspatos e rotação/translação dos fragmentos gerados. O fraturamento e os deslizamentos são responsáveis pelo desenvolvimento de estruturas do tipo pul-apart paralelos e"V"-pull-aparts (Hippertt 1998), muito comuns nos protomilonitos, para o plagioclásio e biotita (Figs. 2a e 2b), e nos milonitos, para o K-feldspato. Além disso, facilitam a percolação dos fluidos e a instalação das reações de hidratação em feldspatos.}

Deformação cristalplástica A deformação plástica foi principalmente observada em cristais de quartzo e de biotita, denunciada pela presença de padrões de extinção ondulante regular e contínua nesses minerais. No quartzo, resultou no deslizamento de discordâncias (dislocations) ao longo dos planos basais (basal $<a>$ ) e conseqüente acumulação de defeitos intracristalinos, principalmente em cristais cujos eixos c orientaram-se em baixo ângulo com a direção de encurtamento máximo.

Abrandamento por reação (reaction softening) As reações que ocorrem em concomitância com a deformação do granitóide de Gouveia envolveram a presença de um fluido rico em água que em contato com o feldspato levaram à sua transformação em mica branca através de reações de hidratação (Fig. 7a). Tais reações ocorrem, preferencialmente, ao longo de fraturas desenvolvidas durante a deformação e marcam um evento metassomático.

O desenvolvimento de pertitas em chamas também marca a atuação de reações sin-deformacionais, principalmente nos domínios de deformações relativamente menores (Fig. 7b). Nos tectonitos amostrados, essas estruturas orientam-se em alto ângulo

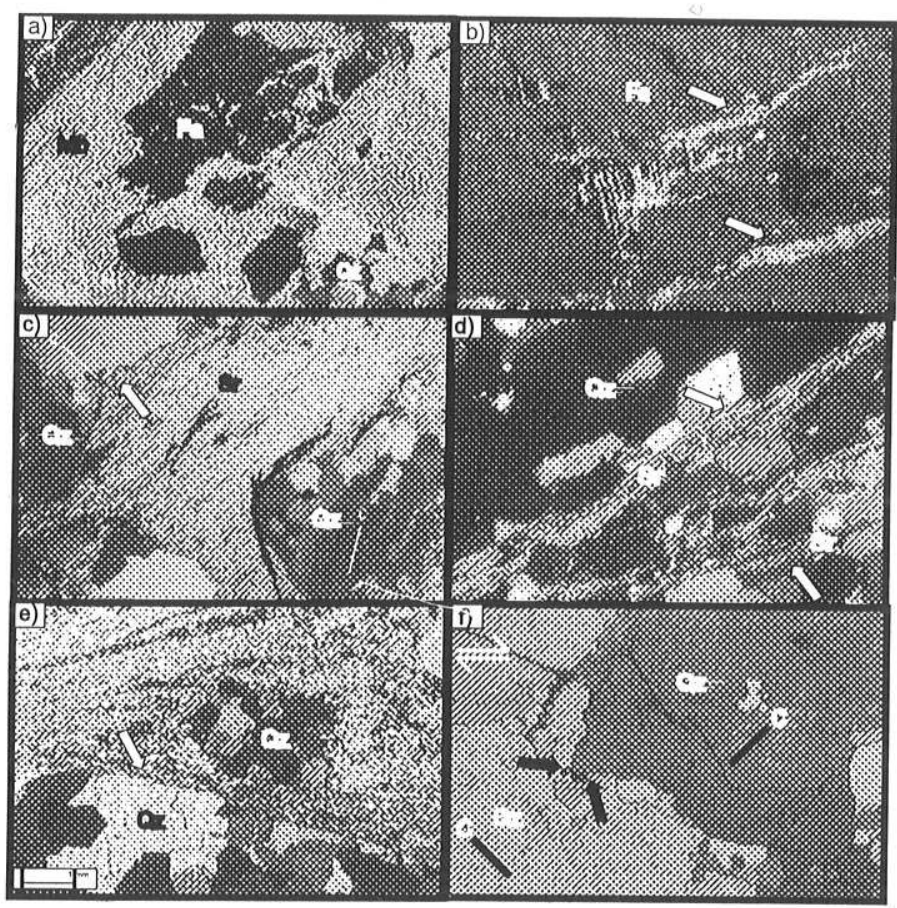

Figura 7 - Processos deformacionais/mecanismos de recristalização atuantes na geração dos tectonitos das zonas de cisalhamento de Gouveia e Serra do Bicho. a) Hidratação em K-feldspato. b) Substituição do K-feldspato pela albita. c, d, e) Dissolução do quartzo. f) Migração de bordas de grão em quartzo. As setas pretas indicam o sentido da migração e as brancas mostram a cinemática da zona de cisalhamento obtida em escala mesoscópica. c = eixo-c de quartzo, $Q z=$ quartzo, $M b=$ mica branca, Sr= sericita. Base das fotos $=$ $1 \mathrm{~mm}$.

com a foliação oblíqua S e sua disposição independe da orientação dos planos de clivagem do K-feldspato. A geração deste tipo de pertita ocorre devido à substituição do K-feldspato pela albita e está relacionada à hidratação do plagioclásio, tal como proposto por Pryer \& Robin (1995).

Dissolução e precipitação de quartzo Os processos de transferência de massa por difusão envolvendo soluções (solution transfer) estão associados com um evento metassomático e ocorreram extensivamente nos tectonitos das zonas de cisalhamento investigadas, concentrando-se, preferencialmente, nos domínios de grandes deformações. Havendo disponibilidade de fluidos, reação nas bordas dos grãos (grain boundary reaction) e difusão intergranular (grain boundary difusion) passam a ser mais importantes que difusão intracristalina (lattice diffusion) e a propagação de discordâncias por saltos (dislocation climb) (Lagoeiro 1998).

A dissolução do quartzo ocorreu, preferencialmente, na sua interface com os minerais micáceos envolvendo, principalmente, cristais cujos eixos-c estivessem em alto ângulo com a foliação oblíqua S. Os cristais de quartzo apresentam-se, freqüentemente, truncados por filossilicatos ou mostrando reentrâncias assemelhando-se a figuras de corrosão (Figs. 7c, 7d e 7e). Nas porções mais deformadas, esse processo levou, inicialmente, à total eliminação de porfiroclastos de quartzo cujos eixos c estavam 
em baixo ângulo com a direção de encurtamento máximo, orientação essa que é desfavorável à ativação de deslizamento ao longo de planos cristalográficos de menor tensão de cisalhamento critica (CRSS) e provavelmente, redundou na maior densidade de defeitos intracristalinos. Além disso, a dissolução do quartzo levou ao desenvolvimento de uma foliação de forma que se orienta em baixo ângulo com a foliação principal.

Os grãos precipitados ao longo da foliação possuem orientação cristalográfica e de forma, ambas em baixo ângulo com a foliação principal (Fig. 8). Diversos autores, tais como Olgaard \& Evans (1986), Hippertt (1994), Lagoeiro (1998), concordam que a presença de planos basais de micas paralelos à foliação oblitera o crescimento de grãos de quartzo, forçando-os a crescerem em direção ortogonal àqueles planos. Além disso, aqueles autores sugerem que o desenvolvimento da orientação preferencial em baixo ângulo com a foliação principal seria o resultado da distribuição anisotrópica da água, que se concentra preferencialmente nos planos de foliação. Resultados semelhantes a esses foram obtidos por Tullis (1989), Hippertt (1994), Hippertt \& Massucatu (1998) e Lagoeiro (1998).

Recristalização por meio da migração de borda de grão e rotação de subgrãos Os mecanismos de recristalização atuam na recuperação de cristais com elevada energia de deformação interna e, no caso estudado, estão restritos às porções com deformações relativamente baixas. A recuperação dos grãos de quartzo se dá por dois mecanismos principais: a migração de bordas de grãos induzida por deformação (Fig. 7f) e a formação e rotação de subgrãos. Feições indicativas da migração de borda de grãos são observadas em bordas de porfiroclastos de quartzo as quais possuem aspecto lobado ou serrilhado. Por meio desse mecanismo, grãos orientados com seus eixos-c em baixo ângulo com a direção de encurtamento máximo são, progressivamente, consumidos por grãos orientados em alto ângulo com aquela direção (Fig. 7c).

Cronologia relativa da ação dos processos deformacionais $\mathrm{A}$ análise microestrutural permitiu estabelecer uma cronologia relativa de ação dos diversos processos deformacionais no curso da evolução das zonas de cisalhamento estudadas (Fig. 9). Na figura 9 demonstra-se que os vários processos descritos não agem isoladamente e nem são exclusivos a uma única classe de tectonitos.

Nas rochas protomiloníticas (Figs. 9 e 10), observou-se uma intrínseca relação entre o fraturamento e a hidratação do plagioclásio. Já os grãos de feldspato alcalino, neste estágio de deformação, fraturam-se muito pouco e são substituídos por albita, na forma de pertitas em chamas. As microestruturas analisadas sugerem que esses processos estão intimamente relacionados e que a atuação do primeiro controla a extensão do segundo. Enquanto os grãos de feldspato são cominuídos e transformados, o quartzo acomoda a deformação por processos cristalplásticos. A foliação ainda é incipientemente desenvolvida e, assim, a interface quartzo/mica, tão importante para que a dissolução do quartzo ocorra, ainda não possui expressão.

Nos milonitos (Figs. 9 e 10), as estruturas primárias do protólito foram totalmente obliteradas e o plagioclásio foi o primeiro mineral a desaparecer. A contínua produção de mica branca leva ao desenvolvimento de uma foliação pervasiva, aumentando a ductibilidade do meio e favorecendo a concentração da deformação. O feldspato alcalino sofre fraturamento e hidratação. Esses resultados corroboram os obtidos por Hippertt \& Hongn (1998), Hippertt \& Massucato (1998). A substituição do K-feldspato pelo plagioclásio deixa de ser o principal processo envolvendo o
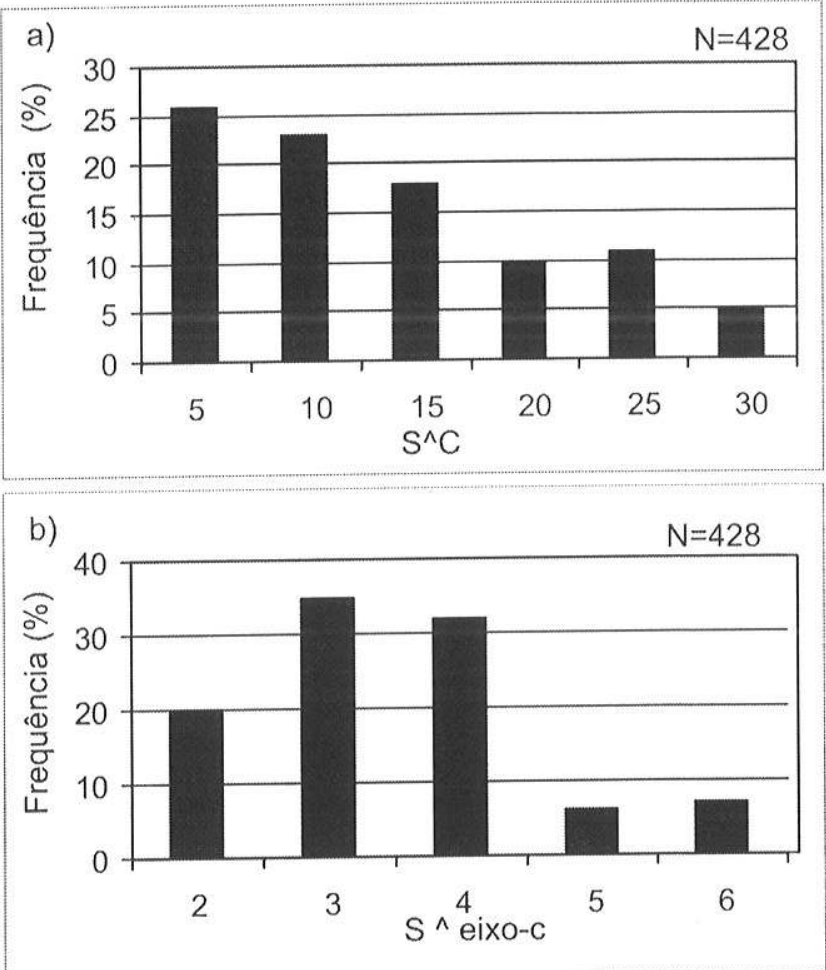

Figura 8 - a) Diagrama de frequiência do ângulo entre o eixo maior dos grãos tabulares de quartzo $(S)$ e a foliação principal (C), nos domínios ricos em mica. b) Diagrama de freqüência do ângulo entre o eixo maior dos grãos tabulares de quartzo (S) e o eixo cristalográfico-c, nos domínios ricos em mica. Né o número de medidas.

primeiro, o que, provavelmente, está relacionado à brusca diminuição no conteúdo do segundo. O balanço de massa realizado por Cruz (2000) mostrou não haver metassomatismo em sódio e cálcio nas zonas de cisalhamento investigadas. Ao que parece, o plagioclásio foi a principal fonte desses elementos. O quartzo passa a ser também deformado por processos assistidos por fluidos em concomitância com a migração de discordâncias.

Nos filonitos (Figs. 9 e 10), a deformação é principalmente acomodada pela dissolução dos grãos de quartzo na sua interface com a mica, pelo desenvolvimento de dobramento de ribbons de quartzo e transposição dos mesmos.

HIDROTERMALISMO NASZONASDE CISALHAMENTODE GOUVEIA E DA SERRA DO BICHO Além da hidratação e da transferência de sílica em pequena escala, descritas anteriormente, o hidrotermalismo tem outros registros nas zonas de cisalhamento investigadas. Silicificação generalizada de setores das mesmas e formação de grandes massas de quartzo como veios de tração (tension gashes), inclusive nas encaixantes, são os mais evidentes. Em algumas zonas, o volume de sílica segregada foi tão intenso que se formaram corpos lenticulares decamétricos de quartzo, dispostos paralelamente à foliação milonítica principal. $\mathrm{O}$ balanço de massa desenvolvido por Cruz (2000) mostrou ganhos de material da ordem de até $0,54 \mathrm{~g}$ para cada $1 \mathrm{~g}$ de rocha original em setores de silicificação intensa. 
A turmalinização é também um processo disseminado nos tectonitos estudados. Foram identificadas duas gerações de turmalinas. A primeira, sintectônica, está posicionada na superfície

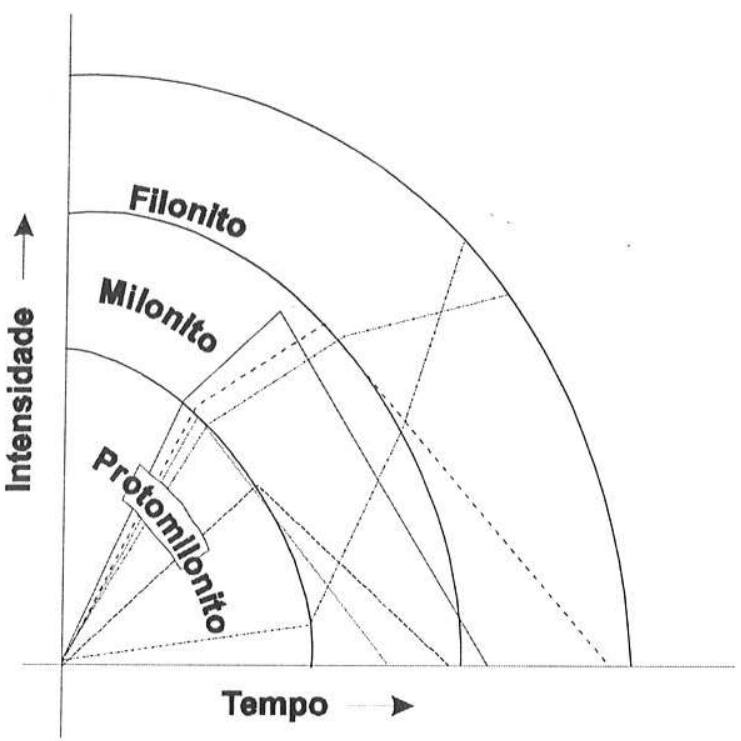

Fraturamento / Deslizamento friccional / Sericitização em feldspatos

Precipitação de quartzo

Dissolução de quartzo

Deformação plástica em quartzo

Desenvolvimento de pertitas em chamas

Mecanismos de Recristalização em quartzo

Figura 9 - Diagrama qualitativo mostrando a importância dos processos deformacionais/mecanismos de recristalização responsáveis pela estruturação da trama na zona de cisalhamento dúctil de Gouveia e da Serra do Bicho. da foliação milonítica, com prismas dispondo-se paralelamente à lineação de estiramento. A segunda, pós-tectonica, não mostra orientação preferencial e os cristais compõem arranjos acicularradiais.

Intercalados aos níveis quartzosos, ocorrem concentrações laminares de barita. O seu posicionamento e a sua ocorrência, invariavelmente associados aos veios de quartzo, sugerem precipitação a partir do mesmo fluido responsável pela filonitização nas zonas estudadas.

Os caminhos para a circulação dos fluidos foram, nos protomilonitos, as fraturas inter e intragranulares. A foliação nessas rochas é extremamente sinuosa e descontínua, implicando baixa difusibilidade ao longo dessa superfície. Nos milonitos e filonitos a circulação do fluido e o transporte de matéria ocorrem, preferencialmente, no contato quartzo/mica. O fluido, nesses sítios, deveria atuar como filme estático de alta difusibilidade, adsorvido na estrutura planar da mica branca, como sugerido em Lagoeiro (1998).

As possíveis fontes de fluido seriam as unidades supracrustais que, envolvidas juntamente com o embasamento na edificação do Anticlinório de Gouveia, experimentaram reações sindeformacionais de desidratação.

\section{ESTIMATIVASDASTEMPERATURASDEMETAMORFISMO,} METASSOMATISMO E DEFORMAÇÃO As transformações mineralógicas no interior das zonas de cisalhamento levaram ao desenvolvimento de uma associação sin-tectônica comum às duas fases de deformação caracterizadas. Compõem essa associação a mica branca (paragonita, pirofilita, moscovita), quartzo, clorita, biotita verde, pirita, epidoto sensu strictu, clinozoizita/zoizita, albita, rutilo, titanita, barita, turmalina, ilmenita e calcita. Como dito anteriormente, tais minerais estão associados com um evento metassomático sin-deformacional. Uma associação metamórfica pós-tectônica em relação aos elementos das fases de deformação envolve cianita, turmalina e mica branca.

Nas rochas do Supergrupo Rio Paraúna, que fazem contato com o granitóide de Gouveia na porção nordeste da área estudada

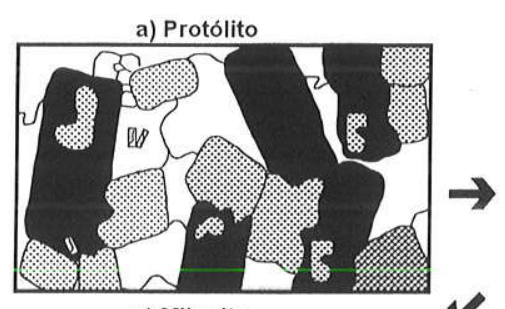

c) Milonito

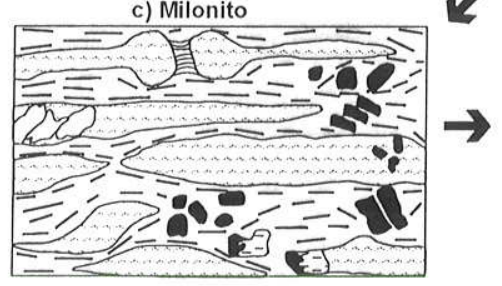

b) Protomilonito

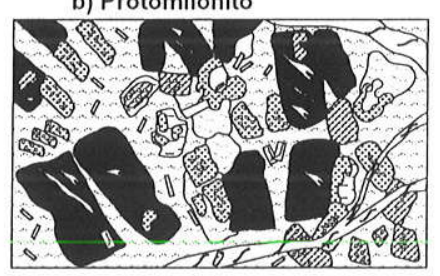

d) Quartzo - Filonito

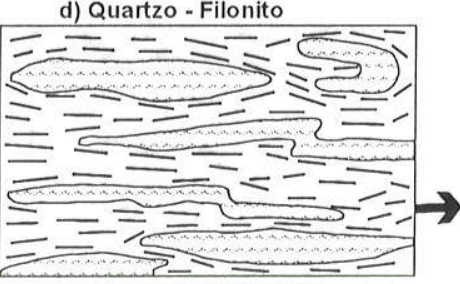

$p i^{m m}$

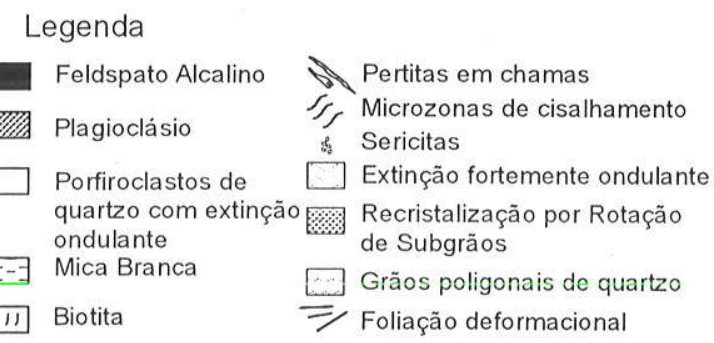

e) Filonito

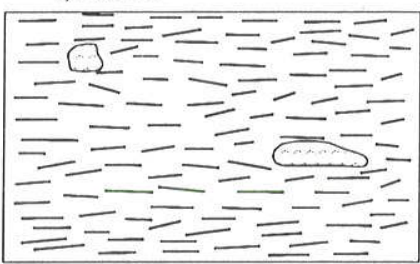

Figura 10 - Modelo para explicar a evolução da trama nos tectonitos presentes no interior das zonas de cisalhamento de Gouveia e Serra do Bicho. 
(Fig. 3), além da associação mineralógica anteriormente citada, observou-se o crescimento de cristais de cloritóide, sem o acompanhamento de estaurolita, o que marca o limite superior da temperatura metamórfica em torno de $500^{\circ} \mathrm{C}$, ou seja, nas condições superiores da fácies xisto verde.

Uma estimativa do limite superior da temperatura de deformação e do metassomatismo a ele associado pode ser feita com base nos processos deformacionais dos feldspatos, bem como na mineralogia pós-tectônica. De um modo geral, como mencionado, os feldspatos comportam-se fragilmente, o que implica temperaturas inferiores a $500^{\circ} \mathrm{C}$ (Voll 1976, Boullier 1980, Tullis 1983, Simpson 1985, 1986, Vauchez 1987). Além disso, em rochas aluminosas a cristalização da cianita, que no caso específico trunca a trama deformacional, ocorre em temperaturas superiores a $400^{\circ} \mathrm{C}$.

A temperatura mínima da deformação e do metassomatismo pode ser estimada com base na ocorrência de recristalização sintectônica do quartzo, que se dá a partir de 250-300 (Voll 1976 , Tullis 1983), como também pela presença de pertitas em chamas. Segundo os trabalhos de Pryer \& Robbin (1991) e Pryer (1993), a formação de pertitas dessa categoria ocorrem em temperaturas entre 300 e $530^{\circ} \mathrm{C}$.

Não existem diferenças quanto aos processos deformacionais que foram responsáveis pela transformação dos diversos minerais em nenhuma das fases de deformação aqui apresentadas. Sendo assim, presume-se que a temperatura durante toda a deformação permaneceu constante e ocorreu num intervalo de temperatura entre $250^{\circ}$ e $400^{\circ} \mathrm{C}$. Já o metamorfismo alcançou os $500^{\circ} \mathrm{C}$, com máximo diacrônico com a deformação. Provavelmente esse fato está relacionado com a ascensão das isotermas em função da extensão final que afetou a cadeia do Espinhaço.

\section{MILONITOS E FILONITOS: CONSTITUIÇÃO E} MICROESTRUTURAS Protomilonitos Protomilonitos fossilizam estágios precoces da deformação (Fig. 11a). Neles estão preservadas texturas e microestruturas do protólito ígneo, destacando-se, no caso presente, a orientação planar dos cristais de tabulares de K-feldspato.

A composição dos protomilonitos reflete a dos seus protólitos. Mesmo assim, importantes modificações modais foram observadas (Fig. 12). Há um sensível decréscimo no conteúdo de plagioclásio, combinado com aumentos nas quantidades de quartzo e mica branca. Foi observado ainda o crescimento de epidoto, zoizita/ clinozoizita, calcita, clorita e titanita.

O microfraturamento é responsável pela destruição de feições primárias de bordas de grãos de feldspatos. A eliminação dessas feições é provocada não só pelo microfraturamento, mas também porque essas descontinuidades passam a ser os sítios preferenciais das reações de hidratação e de substituição do K-feldspato pelo plagioclásio. Bordas curvas e escalonadas são observadas em fragmentos de feldspato imersos em quartzo e mica branca.

O plagioclásio ocorre como fragmentos angulosos a arredondados. Está intensamente fraturado, saussuritizado e tem extinção ondulante irregular e descontínua freqüente. Possui variação granulométrica muito mais ampla do que na rocha original (Fig. 12).

O K-feldspato, pouco fraturado e hidratado, apresenta-se em fenocristais relíctos, orientado segundo a foliação magmática. A principal transformação observada é a sua substituição localizada pela albita, o que dá origem às pertitas em chamas (Fig. 7b). Em função disso, a sua distribuição granulométrica é semelhante àquela apresentada pelos protólitos (Fig. 13).

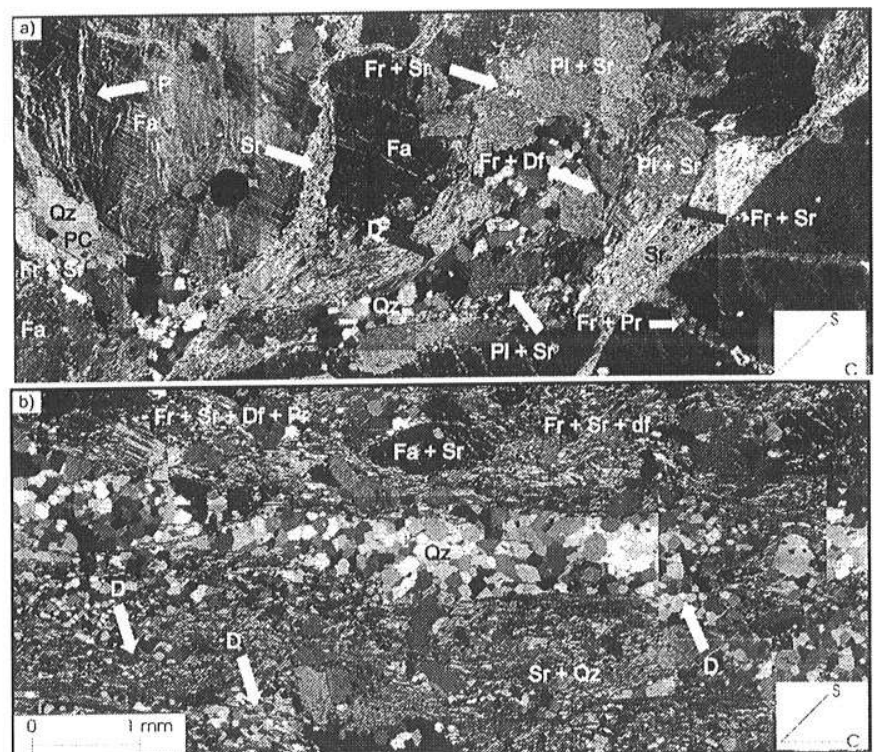

Figura 11 - a) Protomilonito de composição sienogranítica. b) Milonito. As setas indicam os processos deformacionais $(D=$ dissolução, $P=$ Substituição do K-feldspato pelo plagioclásio, $F r=$ fraturamento, $D f=$ deslizamento friccional, $P C=$ plasticidade cristalina, $S r=$ Hidratação, $\operatorname{Pr}=$ precipitação) observados na escala microscópica. $Q z=$ quartzo, $\mathrm{Fa}=$ feldspato alcalino, $\mathrm{Pl}=$ plagioclásio e $\mathrm{Sr}=$ mica branca.
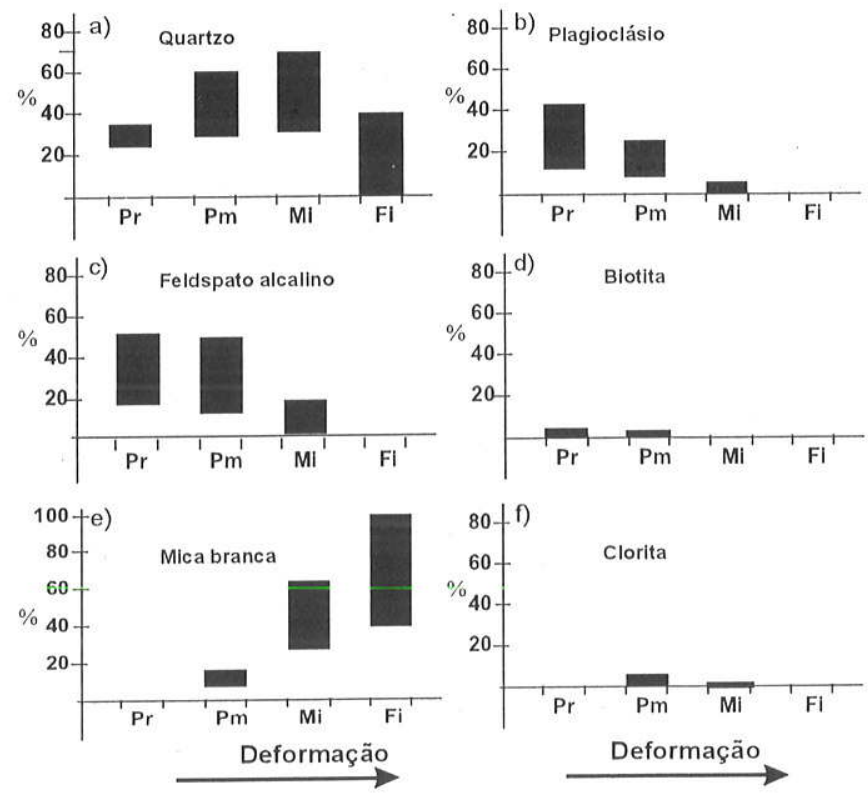

Figura 12 - Variação da composição modal transversalmente às zonas de cisalhamento de Gouveia e da Serra do Bicho. Notar o enriquecimento em mica branca e o empobrecimento em feldspato alcalino e plagioclásio, em direção às porções mais deformadas. $\mathrm{Pr}=$ Protólito, $\mathrm{Pm}=$ protomilonito, $\mathrm{Mi}$ =milonito, $\mathrm{Fi}=$ filonito . 
$\begin{array}{ll}\text { a) Plagioclásio (protólito) } \quad \mathrm{N}=278 & \text { b) Plagioclásio (protomilonito) } \mathrm{N}=265\end{array}$
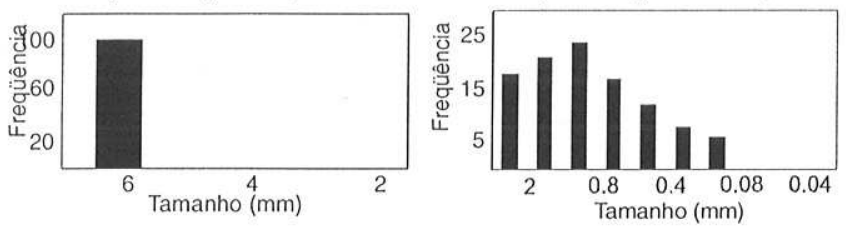

c) Plagioclásio (milonito) $\mathrm{N}=254$

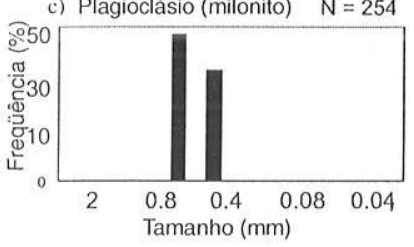

c) F. alcalino (protomilonito) $\mathrm{N}=262$

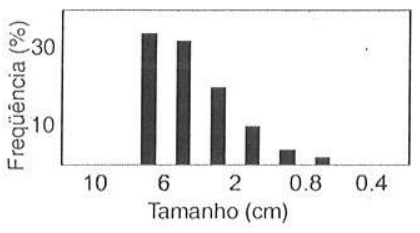

g) Quartzo (protólito) $\quad \mathrm{N}=295$
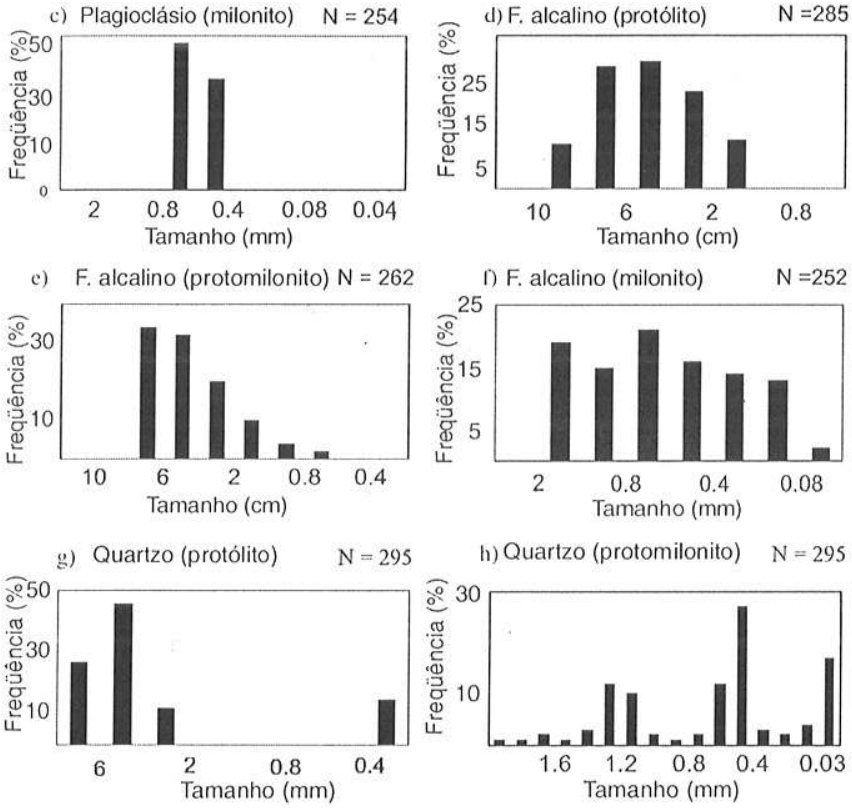

h) Quartzo (protomilonito) $\quad N=295$
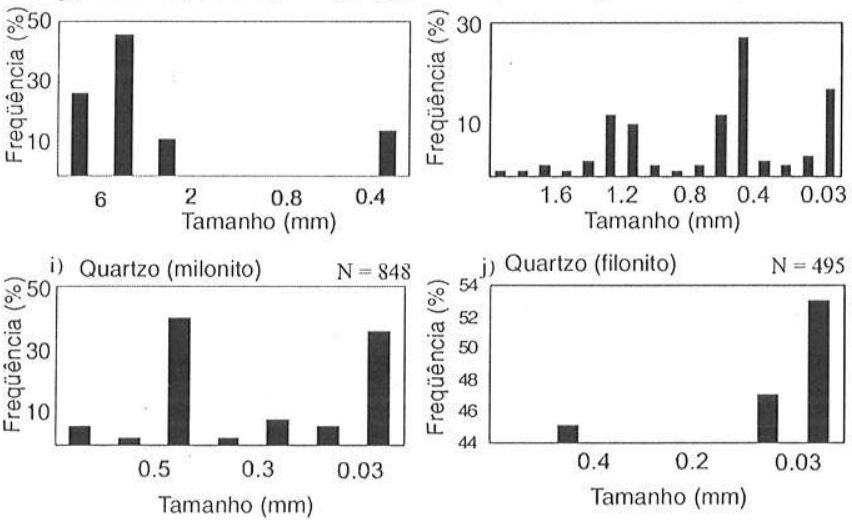

Figura 13 - Distribuição da granulometria do plagioclásio, do K-feldspato e do quartzo em seu protólito ígneo e nas rochas protomilonítica, milonítica e filonítica presentes nas zonas de cisalhamento dúctil-rúpteis encaixadas nas rochas do granitóide de Gouveia.

O quartzo ocorre na matriz, nos interstícios ou contornando os cristais e fragmentos de feldspatos, preenchendo microfraturas em porfiroclastos de feldspato ou em agregados. Os cristais apresentam-se deformados plasticamente, mostrando extinção ondulante. A recuperação desses cristais ocorre pelo mecanismo de rotação de subgrãos (Fig. 7c). A granulometria do quartzo diminui sensivelmente com relação ao protólito ígneo (Fig. 13).

A biotita é verde e ocorre como porfiroclastos sem orientação preferencial, ou inclusa em cristais de feldspato alcalino pertítico. Representa a alteração da biotita castanha primária rica em titânio. Durante a deformação transforma-se em titanita granular, rutilo, ilmenita, clorita e mica branca. A deformação da biotita dá-se, principalmente, no campo plástico, causando intensa extinção ondulante. Cristais orientados com planos de clivagem em baixo ângulo com a direção de encurtamento máximo apresentam-se dobrados. Embora a deformação plástica predomine, observou-se também o desenvolvimento de fraturas ao longo das clivagens.
A mica branca ocorre como produto da alteração sindeformacional/metassomática do feldspato ou como porfiroclastos pseudomórficos. Apresenta inclusões de titanita, ilmenita e rutilo. A deformação ocorre por processos rúpteis. Estruturas tais como micas pisciformes (mica fish) e pull-aparts são freqüentemente observadas (Fig. 4c). Minerais relíctos do protólito como a apatita, zircão, alanita apresentam-se, via de regra, microfraturados.

Milonitos Curiosamente, nas zonas de cisalhamento de Gouveia e da Serra do Bicho, milonitos propriamente ditos são raros. Via de regra, os protomilonitos estão em contato direto com os filonitos, com pouco ou nenhum desenvolvimento dos termos intermediários.

Quando presentes, os milonitos tendem a ocorrer nas porções laterais das zonas estudadas, geralmente, contornados por corpos filoníticos. A principal característica microestrutural observada na transição protomilonito para milonito é a presença de ribbons policristalinos de quartzo e de um nítido bandamento composicional (Fig. I lb). O bandamento desenvolve-se paralelamente à foliação principal e é gerado pela alternância de níveis com quantidades variáveis de microclina, quartzo, plagioclásio, mica branca e/ou biotita.

A principal variação mineralógica observada nos milonitos, quando comparados aos protólitos e aos protomilonitos, é a brusca diminuição no conteúdo de plagioclásio e feldspato alcalino, associada a um aumento no conteúdo em quartzo e mica branca (Fig. 12). No geral, a biotita praticamente deixa de existir nessas rochas, embora em algumas porções das zonas de cisalhamento esse mineral se concentre residualmente.

O plagioclásio, quando presente, ocorre como fragmentos arredondados, em faixas granulométricas bem inferiores aos dos protomilonitos. Estão intensamente hidratados e o microfraturamento não mais representa um processo de deformação importante.

O K-feldspato, por outro lado, mostra-se intensamente microfraturado (Fig. 7a). As fraturas desenvolvem-se ao longo dos planos de clivagem e das pertitas em chamas, permitindo a percolação de fluidos, o desenvolvimento grandes quantidades de mica branca (Fig. 7a) e a importantes modificações na distribuição granulométrica (Fig. 13).

O quartzo ocorre como cristais poligonais no interior de ribbons policristalinos ou como cristais tabulares dispersos na matriz. A deformação desse mineral dá-se, principalmente, pela dissolução ao longo dos contatos com as micas (Figs. 7c, 7d e 7e) e, subordinadamente, pela deformação plástica intracristalina, através do deslizamento de discordâncias (dislocation glide). Desenvolvem-se orientações cristalográficas preferenciais na medida em que aumenta o conteúdo em mica branca e que cristais de quartzo com eixos em baixo ânguló com a direção de encurtamento máximo vão sendo eliminados por dissolução.

Filonitos Filonitos são mais freqüentes na porção central das zonas de cisalhamento e em estreitas bandas no interior de protomilonitos e milonitos (Figs. 14a e 14b). Em afloramento, posssuem foliação paralela com as paredes das zonas de cisalhamento.

Em amostra de mão, os filonitos são muito finos e cinza claro a verde escuro. São constituídos por minerais micáceos, que na maioria dos casos é a mica branca (paragonita, moscovita e pirofilita). Filonitos à biotita e clorita são também comuns. Em algumas amostras, uma trama decussada pode ser observada. É 


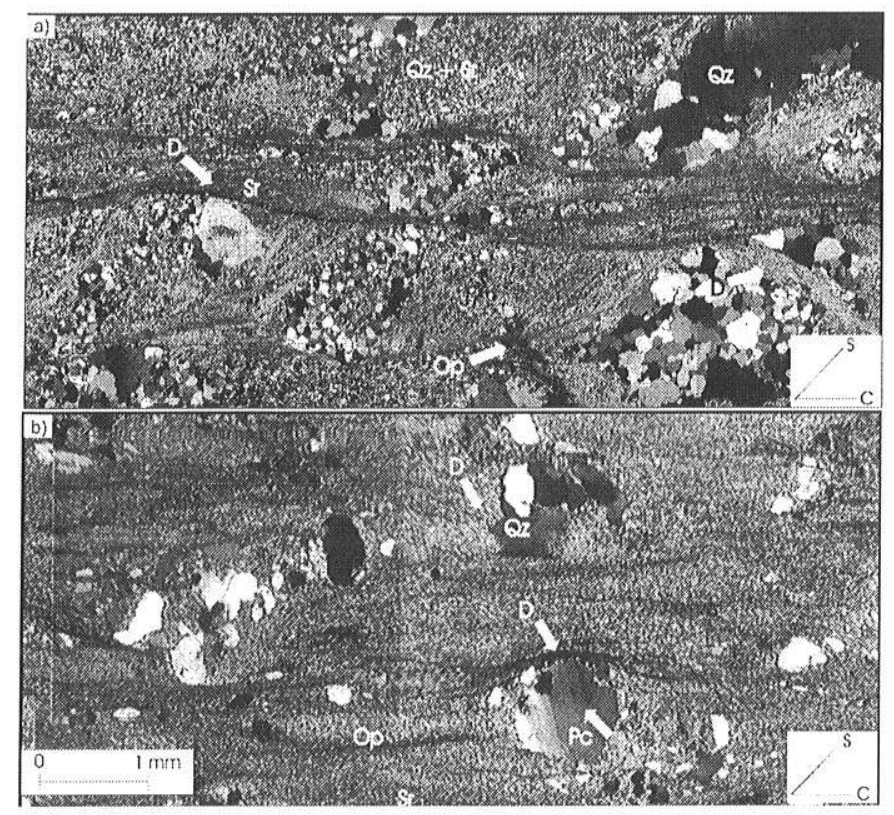

Figura 14 - a e b) Quartzo- mica-branca filonito das porções mais deformadas da zona de cisalhamento de Gouveia. As setas mostram os processos de deformação $(D=$ dissolução, $P c=$ plasticidade cristalina) nessas rochas. $Q z=$ quartzo, $O p=$ opacos e $\mathrm{Sr}=$ mica branca.

conferida à rocha por cristais de turmalina, mica branca e cianita, que truncam a foliação.

Em termos modais, importantes modificações são observadas nesses tectonitos. De maneira geral, observa-se um enriquecimento relativo em mica branca e o desaparecimento completo dos cristais de plagioclásio, K-feldspato e biotita (Fig. 12). Em algumas porções das zonas de cisalhamento, entretanto, nota-se um enriquecimento progressivo em biotita e clorita em direção as porções mais deformadas das zonas de cisalhamento, com geração de biotitaclorita filonitos. Segundo Cruz (2000), a geração de rochas desse tipo deve-se à acumulação progressiva da biotita em função da eliminação dos minerais quartzo-feldspáticos por reações envolvendo um fluido aquoso.

Nos filonitos o quartzo sofre variações negativas em seu volume modal, havendo casos em que praticamente desaparece. Quando ocorre, apresenta-se em cristais alongados, cujo eixo maior orienta-se em baixo ângulo com a foliação principal.

Além da foliação contínua, uma outra feição estrutural diferencia os filonitos dos milonitos. Trata-se de microdobras isoclinais intrafoliais delineadas por ribbons de quartzo policristalino, cujas charneiras variam entre a ortogonalidade e o paralelismo com a lineação de estiramento.

DISCUSSÕESECONCLUSÕES Os resultados aqui obtidos possuem algumas implicações importantes, tanto relativas a tópicos da geologia local, quanto ao conhecimento de que se tem acerca de processos deformacionais em zonas de cisalhamento.

Demonstrou-se que as zonas de cisalhamento de Gouveia e Serra do Bicho são marcadas por faixas de rochas miloníticas e filoníticas, cuja espessura pode chegar até a casa dos 700m. Assim também acontece com as demais zonas de cisalhamento de grande porte do núcleo do Anticlinório de Gouveia (Alkmim 1995). Entretanto, as cartas geológicas disponíveis para a área em questão (vide, por exemplo, Almeida Abreu 1989, Almeida Abreu et al.1992, Fogaça 1996, Knauer \& Fogaça 1996) mostram a maioria das zonas de cisalhamento representadas no mapa da figura 1 como falhas de empurrão acompanhadas, no domínio do núcleo do anticlinório, por xistos atribuídos ao Grupo Costa Sena do Supergrupo Rio Paraúna e não por rochas miloníticas e filoníticas geradas a partir de um protólito ígneo. Xistos de origem não milonítica e também atribuídos ao Grupo Costa Sena, de fato, ocorrem em várias porções do núcleo do anticlinório, inclusive na porção nordeste da área estudada (Fig. 3). Dussin I. A. et al. (1992, 1995) já haviam levantado à hipótese de que as rochas miloníticas presentes nas zonas de cisalhamento do embasamento de Gouveia seriam um dos registros da deformação brasiliana na região.

As rochas miloníticas/filoníticas das zonas de cisalhamento encaixadas no granitóide de Gouveia diferem dos milonitos do Grupo Costa Sena nos seguintes aspectos:

i) As rochas miloníticas/filoníticas mostram passagens graduais para seus protólitos graníticos, marcadas por aumentos progressivos na geração de matriz de filossilicatos.

ii) Elas exibem uma grande "monotonia" composicional, marcada por quantidades variáveis de quartzo e filossilicatos, com proporções variáveis de feldspato e turmalina. São destituídos do bandamento e da diversidade composicional dos metassedimentos. iii) Tais rochas ocorrem em faixas de alto ângulo de mergulho, com atitude modal média em torno de 090/60. Os xistos do Grupo Costa Sena, ao contrário, afloram em zonas e faixas muito mais espessas, de mergulho consideravelmente mais baixo, e que, além disso, mostram, internamente, uma arquitetura muito mais complexa. Em geral exibem pelo menos duas gerações de dobras de estilos e escalas variáveis.

As zonas de cisalhamento de Gouveia e da Serra do Bicho registram movimentos reversos-sinistrais e normais-dextrais, ocorridos em duas fases distintas, responsáveis, respectivamente, por sua nucleação e reativação. Em função da sua continuidade na cobertura metassedimentar, sem mudança de vergência e significado tectônico, o pode-se afirmar que o seu desenvolvimento deu-se em concomitância com a principal fase de edificação do Cinturão Araçuaí que, segundo vários autores (dentre outros, Uhlein 1991, Pedrosa-Soares et al. 1992, Dussin, I. A., 1994, Dussin I. A. et al. 1992, 1995, Dussin I. A. \& Dussin T. M. 1995) deu-se no curso do Evento Brasiliano. As reativações normais observadas podem, por seu turno corresponder a uma manifestação local colapso orogenético que experimentou o orógeno Araçuaí-Oeste Congo, tal como sugerido por Alkmim et al. (2002).

Além destes pontos, pode-se concluir ainda que:

i) A geração das zonas de cisalhamento foi diretamente controlada pela trama primária preexistente, resultando no seu alto ângulo de mergulho.

ii) Processos deformacionais e metassomatismo atuaram em conjunto no curso da evolução das zonas de cisalhamento. Na escala de grão os principais processos foram fraturamento/ hidratação de K-feldspato, plagioclásio, mica branca e biotita, com rotação dos fragmentos gerados, dissolução dos grãos de quartzo na sua interface com a mica, deformação plástica de grãos de quartzo e biotita por propagação de discordâncias (dislocation glide), substituição do K-feldspato pelo plagioclásio e saussuritização do plagioclásio. Os mecanismos de recristalização do quartzo ficaram restritos às porções menos deformadas das zonas de cisalhamento.

iii) $O$ desenvolvimento da orientação preferencial de quartzo nas porções mais deformadas, sejam elas cristalográficas ou de forma, 
deve-se à dissolução daquele mineral, em função do elevado conteúdo em mica e da sua orientação cristalográfica original. Além disso, a precipitação com crescimento anisotrópico do quartzo ao longo do seu eixo-c também se constitui como um importante processo na geração da orientação de forma.

iv) Da periferia para o centro das zonas de cisalhamento, de uma maneira geral, há progressiva diminuição no conteúdo de plagioclásio, feldspato alcalino, biotita, clorita e quartzo e enriquecimento progressivo em mica branca. Em algumas zonas observou-se, porém, um grande aporte de sílica, que se expressa na forma de veios de quartzo. As principais fontes de sílica, neste caso, foram as reações de hidratação que levaram à filonitização no interior das zonas de cisalhamento.

v) A presença de fluidos foi fundamental para a nucleação e desenvolvimento das zonas de cisalhamento estudadas. Eles foram responsáveis pelo desenvolvimento de reações de hidratação em feldspato que levaram à formação de grandes volumes de filonitos, pela dissolução dos grãos de quartzo e pelo transporte dos produtos daquelas reações.

vi) Tendo em vista as microestruturas observadas conclui-se que a temperatura de deformação e do metassomatismo, para ambas as fases, variou no intervalo entre 300 e $400^{\circ}$ C. A associação metamórfica observada reflete as condições de fácies xisto verde, com temperatura atingindo $500^{\circ} \mathrm{C}$ e não se restringe às zonas de cisalhamento dúctil-rúpteis estudadas. Está também registrada nos xistos do Grupo Sena.

Agradecimentos O presente estudo foi desenvolvido no âmbito de uma tese de mestrado apresentada ao Programa de PósGraduação do DEGEO/UFOP, ao qual expressamos nossos agradecimentos. S. C. P. Cruz foi contemplada pelo CNPq com bolsa de mestrado. F.F.Alkmim recebe auxílio do CNPq na forma de bolsa de produtividade em pesquisa, processo $n^{\circ} 300833 / 99-7$. Aos colegas Guilherme Gravina Peres e Rafael Romano pelo auxilio na aquisição e organização das fotomicrografias e aos revisores anônimos pelas sugestões ao manuscrito.

\section{Referências}

Alkmim, F.F. 1995. O Anticlinório de Gouveia: Exemplo de culminação antiformal nucleada pelo embasamento. In: SBG, Simp. Geol. Minas Gerais, 8, Anciis, p. 1-2.

Alkmim, F. F., Marshak, S., Pedrosa-Soares, A. C. 2002. O registro estrutural do colapso da porção brasileira do orógeno Araçuaí-Oeste Congo. In: SBG, Congresso Brasileiro de Geologia, 46, Anciis, p. 287-288,

Almeida Abreu, P.A. 1985. Mapa geológico da Quadrícula de Cuiabá (1:25.000). Centro de Geologia Eschwege, Universidade Federal de Minas Gerais.

Almeida Abreu, P.A. 1989. Geologia da quadrícula Onça e Cuiabá (Gouveia-MG) - região mediana central da Serra do Espinhaço Meridional. Dissertação de Mestrado, Instituto de Geociências, Universidade Federal do Rio de Janeiro, 66p.

Almeida Abreu, P.A., Pflug, R., Schorscher, H.D. 1992. Cover/ Basement relationships in the southern Serra do Espinhaço, Minas Gerais, Brazil. Zbl.Geol. Paläiont, I: 1749-1760.

Boullier, A. M. 1980. A preliminary study on the behavior of brittle minerals in a ductile matrix: example of zircons and feldspars. Journ. Struct. Geol., 1/2: 211-217.

Cruz, S.C.P. 2000. Zonas de Cisalhamento no mícleo do Anticlinal de Gouveia: Processos

deformacionais e metamórficos. Dissertação de Mestrado, Departamento de Geologia, Universidade Federal de Ouro Preto, 277p.

Dossin, I.A., Uhlein, A., Dossin, T.M. 1984. Geologia da faixa móvel Espinhaço em sua porção meridional, MG. In: SBG, Cong. Bras. Geol., 33, Anais, p. 3118-3132.

Dussin, T. M. 1994. Associations volcano-plutoniques de l'Espinhaço meridional (SE-Bresil): Um d'évolution de la croût Proterozoïque. Tese de Doutorado, Iniv. Orléans, 177p.

Dussin, T. M., Dussin, I. A., Charvet, J. 1996. Lamprófiros Calco-Alcalinos da Região do Espinhaço Meridional (MG): Petrologia e Contexto Tectônico. In: SBG, Cong. Brás. Geol., 39, Anais p. 235-238.

Dussin, I. A.1994. Evolution Structurale de la region de l'Éspinhaşo Meridional, bordure Sud-est du Craton São Francisco, Brésil Tectoniques Superperposées au Proterozïque. Tese de
Doutoramento, Université D’Orleans, 200p.

Dussin, I. A. \& Dussin, T. M. 1995. Supergrupo Espinhaço: Modelo de Evolução Geodinâmca. Geonomos, 1: 19-26.

Dussin, I. A., Charvet, J., Charvet, A., Faure, M., Dussin, T. M. 1995. Tectônica Transamazônica na Região do Espinhaço Meridional (MG): Evidência Microestrutural e Petrotrama de Quartzo. In: SBG, Simp. Nac. Est. Tect., 5, p. 121-123.

Dussin, I. A., Dussin, T. M., Charvet, J., Chemale jr: 1992. Tectonique du Protérozoïque Supérieur au sud-est du Craton São Francisco (minas Gerais, Brésil). Comptés Rendus de L'Académie des Sciences Serie II - Fascicule, II: 629-636.

Fogaça, A.C.C., Almeida Abreu, P.A, Schorscher, H.D. 1984. Estratigrafia da sequêencia arqueana na porção mediana central da Serra do Espinhaço, Minas Gerais. In: SBG, Cong. Bras. Geol., 33, Ancis, p. 2654-2667.

Fogaça, A.C.C. 1996. Mapa Geológico da Folha Diamantina, Minas Gerais, Brazil. Universidade Federal de Minas Gerais, Instituto de Geociências, Companhia Mineradora de Minas Gerais, COMIG - Projeto Espinhaço, Folha SE-23-Z-A-III.

Fogaça, A.C.C. \& Schöll, W.U. 1984. Estratigrafia e tectônica das rochas arqueanas e proterozóicas da região de Guinda e Gouveia (MG). In: SBG, Cong. Bras. Geol., 33, Anciis, p. 2638-2651.

Hippertt, J.F.M., 1994, Grain boundary microstructures in micaceous quartzite: Significance for fluid Movement and Deformation Processes in Low Metamorphic Grade Shear Zones. Journ. Geol., 102: $331-348$

Hippett, J.F. \& Hongn, F.D. 1998. Deformation mechanisms in the mylonite/ultramylonite transition. Journ. Struct. Geol., 1: 1-14.

Hippertt, J.F \& Massucattu, A.J. 1998. Phyllonitization and development of kilometer-size extension gashes in a continental-scale strike-slip shear zone north Goiás, central Brazil. Journ. Struct. Geol., 4: 433445 .

Hoffmann, C. 1983. The Archean peraluminous Gouveia Granite: its structures, geochemistry and phase petrology (Serra do Espinhaço, Minas Gerais, Brazil). N. Jb. Min., 2: 359-371.

Hoffmann, C. \& Hoppe, A. 1981. Metamorphism and petrology of basic 
rocks of the southern' Serra do Espinhaço (Precambrian, Eastern Brazil). Zbl. Geol. Paläont, I: 359-371.

Ivins, E.R., Dixon, T.H., GolombeK, M.P. 1990. Extensional reactivation of an abandoned thrust: a bound on shallowing in the brittle regime. Journ. Struct. Geol., 3: 303-314.

Knauer, L.G \& Fogaça, A.C.C. 1996. Mapa geológico da Folha Presidente Kubitschek, Minas Gerais, Brazil. Univeridade Federal de Minas Gerais, Instituto de Geociências, Companhia Mineradora de Minas Gerais, COMIG - Projeto Espinhaço, Folha SE-23-Z-A-VI

Lagoeiro, L.E. 1998. Mecanismos de deformação e orientações cristalográficas preferenciais em tectonitos se Formação Ferríferas-Quadrilátero Ferrífero, $M G$. Tese de Doutoramento, Instituto de Geociências, Universidade de São Paulo, 160p.

Machado, N., Schrank, A., Abreu, F.R., Knauer, L.G., Almeida Abreu, P.A. 1989. Resultados preliminares da geocronologia $\mathrm{U} / \mathrm{Pb}$ na serra do Espinhaço Meridional. Bol. Soc. Bras. Geol., 10: 171-174.

Olgard, D.L. \& Evans, B. 1986. Effect of second-phase particles on grain growth in calcite. Journ. Amer: Ceram. Society, 69: 272-277.

Pedrosa-Soares, A.C.P., Noce, C.M., Vidal, P.H., Monteiro, R.L.B.P., Leonardos, O.H. 1992. Toward a new model for the Late Proterozoic Araçuaí (SE Brazil) - West Congolian (SW Africa) Belt. Journ. South Amer: Earth Sci., 1/ 2: 22-47.

Pflug, R. 1965. A geologia da parte meridional da serra do Espinhaço e zonas adjacentes. Rio de Janeiro, DNPM/DGM, Boletim 226, 51p.

Pryer, L.L. 1993. Microstructures in feldspar from a major crustal thrust zone: The Greenville Front, Ontario, Canadá. Journ. Struct. Geol., 15: 21-36.

Pryer, L.L. \& Robin, P. Y. F. 1991. A model for albite flame growth. Terra Abstract, 5: 32 .

Pryer, L.L. \& Robin, P.Y.F. 1995. Retrograde metamorphic reactions in deforming granites and the origin of flame perthite. Journ. Metam. Geol., 13: 645-659.

Rosière, C.A., Uhlein, A., Fonseca, M.A., Torquato, J.R. 1994. Análise cinemática dos cavalgamentos do cinturão Espinhaço na região de Diamantina, MG. Rev. Bras. Geoc., 2: 97-103.

Schobbenhaus, C., Campos, D. A., Derze, G. R., Asmus, H. 1981. Mapa Geológico do Brasil, 1:2.500.000. Folha Belo Horizonte. Brasília, MME/DNPM. Mapa Geológico.

Schöll, W.U. \& Fogaça, A.C.1979. Estratigrafia da Serra do Espinhaço na região de Diamantina. In: SBG, Simp. Geol. Minas Gerais, 1, Atas, p. 276-290.

Schöll, W.U. \& Fogaça, A.C.C. 1981. Geologia da Quadrícula de Guinda \& Gouveia. Diamantina, Centro de Geologia Escheweg, 63p.

Sibson, R.H., 1977. Fault rocks and fault mechanisms. Journ. Geol. Soc. London, 133: 197-213.

Sibson, R. H. 1990. Faulting and fluid flow. MAC Short Course on Crustal Fluids Handbook, 18: 94-131.

Silva, R.R. 1995. Contribution to the stratigraphy and paleogeography of the lower Espinhaço Supergroup (Mesoproterozoic) between Diamantina and Gouveia, Minas Gerais, Brazil. Tese de Doutoramento, Universidade de Freiburg, 115p.

Simpson, C. 1985. Deformation of granitic rocks across the brittle-ductile transition. Journ. Struct. Geol., 5: 503-511.

Simpson, C. 1986. Fabric development in brittle-to-ductile shear zones. Pure appl. Geophysic, 124: 269-288.

Tullis, J. 1983. Deformation of feldspar, In: Ribbe, P.H (ed), Feldspar Mineralogy. Mineralogical Society of America, Washington, 2: 297 323.

Tullis, T.E. 1989. Development of preterred orientation due to anisotropic dissolution/growth rates during solution-transfer creep. EOS Trans. Am. Geophys. Union, 70: 457-458.

Uhlein, A. 1991. Transição Cráton-faixa dobrada: exemplo do Cráton do São Francisco e da Faixa Aracuaí (Ciclo Brasiliano) no estado de Minas Gerais. Apectos estratigráficos e Estruturais. Tese de Doutoramento, Instituto de Geociências, Universidade de São Paulo, 295p.

Uhlein, A. Dossin, I.A., Chaves, M.L. 1986. Contribuição à geologia estrutural e tectônica das rochas arqueanas e proterozóicas da Serra do Espinhaço Meridional. In: SBG, Cong. Bras. Geol., 33, Anais, p. 1191-1199.

Vauchez, A. 1987. The development of discret shear-zones in a granite: Stress, strain and changes in deformation mechanisms. Tectonophysics, 133: 137-156.

Voll, G. 1976. Recrystallization of quartz, biotite and feldspar from Erstfeld tothe Leventina nappe, Swiss Alps, and its geological significance. Schweiz. Mineral. Petrogr: Mitt., 56: 641-647.

Manuscrito A 1327
Recebido em 07 de março de 2002 Revisão dos autores em 30 de novembro de 2005 Revisão aceita em 12 de dezembro de 2005 